\title{
CAUSAL RELATIONSHIP BETWEEN SUPPLY CHAIN DYNAMIC CAPABILITIES, TECHNOLOGICAL INNOVATION, AND OPERATIONAL PERFORMANCE
}

\author{
Ki-Jung Ju${ }^{1}$, Byeonghwa Park², Taikyoo Kim ${ }^{2}$ \\ 1 Technical Commercialization Team Regional Industry Promotion Agency, Daegu Technopark, Korea \\ ${ }^{2}$ Department of Business Statistics, Hannam University, Korea \\ Corresponding author: \\ Taikyoo Kim \\ Department of Business Statistics \\ Hannam University \\ 70 Hannam-ro, Daedeok-gu, Daejeon, 34430, Korea \\ phone: (+82 42) 629-7621 \\ e-mail: taikyoo@korea.com
}

Received: 1 July 2016

Accepted: 28 July 2016

\begin{abstract}
The aim of this study is to empirically examine the impact of supply chain dynamic capabilities on operational performance, and the mediating effect of technological innovation between dynamic capabilities and operational performance. This study is based on empirical data collected from a survey of 206 small- and medium-size firms in Korea. Structural equation modeling is used to test the research questions. The results show that supply chain dynamic capabilities positively influence technological innovation and operational performance of an enterprise. Additionally, structural equation analyses reveal that technological innovation plays a role as a partial mediator of the relationship between supply chain dynamic capabilities and operational performance. In a dynamic and ever-changing environment, the enforcement of dynamic capabilities in a sustainable supply chain is important for the innovation of technology and the improvement of operational performance. Further investigation is required to understand the differences by industries, characteristics of enterprises, and positions in a supply chain.
\end{abstract}

KEYWORDS

supply chain management, dynamic capabilities, supply chain dynamic capabilities, technological innovation, operational performance.

\section{Introduction}

Due to the acceleration of the global economy, the rapid progress of information technology, and the various expectations of customers, today's business environment is rapidly changing and competition among enterprises has intensified. In the past the technology transfer from one industry to another did not occur or was a slow process. Due to the rapid growth of technological innovation and globalization, a technology developed for one industry is quickly transferred to another. This creates a great ripple effect throughout the industry. This ever-changing business environment prevents enterprises from sus- taining their competitive positions as well as from allowing for the time necessary to diagnose changes in the business environment, discover opportunities and risks, and to deal with them in a timely manner.

Therefore, the dynamic capabilities theory has been implemented in business environments where dynamic capability is required in order for an organization to remain sustainable. Dynamic capability refers to the capability of an organization to integrate and reorganize its internal and external resources [14]. By implementing the dynamic capabilities theory, an organization is given the opportunity to create enterprise values such as management innovation, sus- 
tainable competitive advantage, and operational performance through dynamic capability. The dynamic capabilities theory is based on the resource-based view $[5,6]$ and the core competency theory $[7,8]$. According to the resource-based view, organizational performance is created from the capability and differences in resources an organization holds, which are valuable, rare, imperfectly imitable, and nonsubstitutable [6]. The idea of core competency was introduced by Prahalad and Hamel [8]. They assert that core competencies differentiate organizations from rivals and are sources of competitive advantage and can be improved from learning and sharing. Conditions of core competencies specified by Prahalad and Hamel [8] are: capability to create customer values, capability to differentiate organization from rivals, scalability to apply to other areas, and difficulty for competitors to imitate in a short period of time.

This study proposes supply chain dynamic capabilities as a required capability in order to gain a sustainable competitive position in a rapidly changing business environment. In the current competitive market, competition among organizations switches to competition among supply chains. Thus, the competitive position and operational performance of an organization depends on its supply chain capability. Supply chain management is defined as the systemic, holistic coordination which results from producing products or delivering services all the down to consuming them, for the purposes of creating excellent customer value and gaining competitive advantages [9]. For successful supply chain management, an organization integrates various functional areas within the organization. This integration effectively links activities performed by suppliers, distributors, and customers outside the organization, promoting the improvement of operational performance and competitiveness. Supply chain management allows organizations to concentrate on core competency, affects future competitiveness, and changes competition between supply chains rather than between organizations $[10,11]$. Improving supply chain capabilities is important in order to enhance sustainable competitive advantage between supply chains [12]. In a dynamic environment where uncertainty is high, it is difficult for traditional efficiency-oriented supply chains to respond to changes in the business environment. From the dynamic capabilities standpoint, organizations need to improve supply chain performance. The enhancement of supply chain dynamic capabilities, which enables the organization to adapt to changes, is very important to successfully sustaining the organization's competitive positions and long-term profitability [13, 14].
As uncertainty in the business environment is increased and operational ability becomes equal, technological innovation receives attention as a strategic alternative to secure and retain a competitive advantage through the enhancement of an organization's adaptability to the environment [15-17]. When an organization enhances technological innovation from the perspective of operations management based on the innovation strategy of an organization, operational performance can be improved and competitors will be hard pressed to imitate this technological in a short period of time. As a result, the organization can acquire long-term competitive capabilities. Technological innovation improves both quality and flexibility, and reduces lead time and cost, thus affecting the competitive advantage of an organization in the marketplace.

This study empirically analyzes the impact of supply chain dynamic capabilities on operational performance and examines the mediating effect of technological innovation. Supply chain management influences various functional areas throughout an organization such as operations management, marketing, and finance. In particular, operational performance has been set up as an outcome variable because there is a strong correlation between supply chain management and the improvement of operational performance from the perspective of operations management. Previous literature has found an association between supply chain management and operational performance [18, 19]. In addition, Kristal et al. [11] claim that a positive relationship exists between supply chain management and operational performance. Maintaining a collaborative buyer-supplier relationship enables an organization to reduce transaction costs and improve operational performance by improving quality, decreasing lead time, and acquiring flexibility in production capacity [20, 21]. This study proposes under the current uncertain business conditions supply chain, dynamic capabilities are a more appropriate response for today's business environment and also should be enhanced in order to improve the operational performance of an organization. Furthermore, this study empirically examines how technological innovation mediates the relationship between supply chain dynamic capabilities and operational performance.

\section{Theoretical background and hypothesis}

\section{Dynamic capabilities theory}

Dynamic capabilities come to the forefront when uncertainty in the business environment is high. 
Teece and colleagues [3] define dynamic capabilities as the organization's ability to integrate, build, and reconfigure technologies, resources, and functions inside and outside the organization in order to adapt to continuously changing environments. Other researchers define dynamic capabilities as the organizational and strategic routines by which firms achieve new resource configurations as markets emerge, collide, split, evolve, and die [2: p. 1107]. Therefore, dynamic capabilities enable organizations to achieve competitive advantage through a mechanism that continuously implements a strategy based on environmental changes [22].

Characteristics of dynamic capabilities identified by previous research [2-3] can be summarized as follows: 1) dynamic capabilities consisting of strategic and organizational processes that create value for organizations in changing business environments, 2) since dynamic capabilities show that best practice is common in effective organizations, implementation performance is predictable. Also, these dynamic capabilities evolve based on unique paths shaped by learning mechanisms and can be developed further through various learned knowledge such as practice and mistakes, 3) patterns of dynamic capabilities are various. Under the stable industry structure, they rely on existing knowledge and produce predictable outcomes. Under the unstable industry structure, however, they rely on new knowledge created recently and produce unpredictable outcomes, and 4) dynamic capabilities reflect the management capabilities of an organization. In order to respond to changing environments and expedite the pace of innovation, an organization has to adjust and relocate resources and capabilities based on its management process and market positions.

\section{Supply chain dynamic capabilities}

Supply chain management is a holistic approach which allows for the management of each individual stage of the process from procurement of raw materials to delivery of goods in order to create excellent customer value and acquire competitive advantage. Supply chain integration and firm performance are topic that have been highly researched and many studies show that there is a positive relationship between the two [23-26]. Much research has been done on the development of highly efficient supply chains. However, if an organization pursues only the efficiency of supply chains, it will not be capable of rapidly responding to the present fastchanging business environment due to the effects of a shortened product lifecycle, turbulent world situation, changes in national policy as well as supply and demand [27]. Short-term supply and demand imbalances can also have a negative impact on supply chain efficacy. Excess cost is incurred from maintaining inventory due to the failure of accurately forecasting market demand. Also, if there are longterm market structural changes, efficiency of supply chains is not easily achieved. Therefore, an organization must have capabilities to implement the of appropriate strategies required for uncertain, changing environments [15]. In order to enhance supply chain dynamic capabilities, an organization has to develop a responsive supply chain through increased collaboration with other organizations in supply chains $[28,29]$. Early research where the dynamic capabilities theory was applied to supply chains mainly focused on the bullwhip effect that arises from the lack of information sharing among organizations in the supply chain. Similar to supply chain dynamic capabilities, successful organizations create supply chains that are agile, adaptable, and aligned, which is termed Triple-A Supply Chain by Lee [27]. An organization implementing Triple-A Supply Chain responds to changing markets, coordinates business processes by sharing information, risks and benefits, and enhances competitiveness of supply chain partners as well as improves the performance of individual organizations. Primary focus among organizations in the supply chain component often leads to the detriment of other components. Therefore, in order to reflect customer needs and ensure sustainable competitive advantage in a dynamic environment, the following additional components are necessary: information sharing, supply chain alignment, information technology integration, and supply chain dynamic capabilities which respond to changes.

\section{Technological innovation}

Innovation plays an important role in developing an organization's adaptability in an uncertain changing business environment. Innovation internalized by organizations is rare, valuable, and difficult for rivals to imitate.

From the literature review, innovation can be broken down into different types: radical versus incremental, exploitative versus exploratory, administrative versus technical, and product versus process. Radical innovations produce fundamental changes and show clear departures from existing practices, whereas incremental innovations result in little departure from existing practices [30, 31]. Exploitative innovations refer to improvement of existing products or services and are similar to incremental innovations, whereas exploratory innovations involve 
introduction of new products or services to meet customer and market needs and are similar to radical innovations $[32,33]$. Since the interest of this study lies in technical innovations, discussion of technical and administrative innovations is provided in more detail. Technical innovations pertain to new technology, products, and services whereas administrative innovations are associated with new processes, policies, and organizational structure [34]. In this sense, technical innovations can be divided into product and process innovations. Product innovations are new, and successful products or services developed and introduced into the marketplace. Process innovations are adoptions of new production or service operations. Other research also categorizes technical innovation into lower dimensions: product innovation and process innovation $[35,36]$. However, the boundaries between product innovation and process innovation seem to be unclear because product innovation may result in process innovation and vice versa [36]. These two types of innovations can be understood as being complementary relationships.

\section{Operational performance}

Performance measurement is responsible for the alignment of the strategic goals of an organization and the implementations of its plan [37]. Since an organization's performance is accomplished through the various activities of the management process, it has multidimensional characteristics. An organization's goals and objectives should be related to the performance achieved through these goals and objectives. When challenged by fierce global competition, an organization has to achieve high performance in various areas in order to obtain and maintain competitiveness. As an organization grows through advanced manufacturing technology, introduction of world-class manufacturing prac- tices, and global competition, it improves its multidimensional operational performance. An organization that has achieved superior performance in one area can synergistically improve another through learning [38]. A multidimensional measure of operational performance is conceptualized as an intended or realized competitive performance and is assessed by cost, quality, flexibility, and delivery measures [39-41].

\section{Relationships between supply chain dynamic capabilities, technological innovation, and operational performance}

This study proposes a research model based on a theoretical background reviewed in earlier sections and empirically tests these hypotheses. The research model shown in Fig. 1 shows supply chain dynamic capabilities as a second-order construct consisting of supply chain information sharing, supply chain collaboration, supply chain integration, and supply chain agility. In addition, technological innovations encompassing product and process innovations are viewed as a second-order construct. The hypotheses of this study are as follows:

Hypothesis 1: Supply chain dynamic capabilities have a positive impact on technological innovation.

Hypothesis 2: Supply chain dynamic capabilities have a positive impact on operational performance.

Hypothesis 3: Technological innovation has a positive impact on operational performance.

Hypothesis 4: Technological innovation mediates the relationship between supply chain dynamic capabilities and operational performance.

The research model and measurement instruments for hypothesis testing in this study have been modified from previous research and detailed information on the measurement instruments can be found in Table 1.

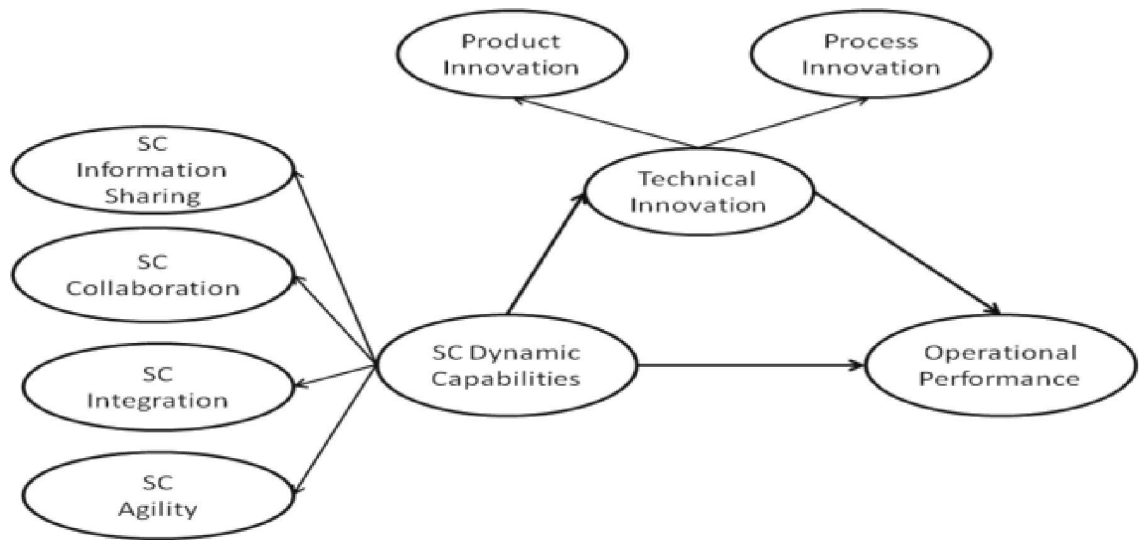

Fig. 1. A research model: relationship between supply chain dynamic capabilities, technological innovation, and operational performance. 
Table 1

Measurement instrument and related research.

\begin{tabular}{|c|c|c|c|}
\hline Variable & \multicolumn{2}{|r|}{ Measurement instrument } & $\begin{array}{l}\text { Related } \\
\text { research }\end{array}$ \\
\hline \multirow{4}{*}{$\begin{array}{c}\mathrm{SC} \\
\text { Information } \\
\text { Sharing }\end{array}$} & $\mathrm{sc} 1$ & Demand information sharing with partners & \multirow{16}{*}{$11,42,43$} \\
\hline & sc2 & Cost information sharing with partners & \\
\hline & $\mathrm{sc} 3$ & Risk and performance allocation with partners & \\
\hline & $\mathrm{sc} 4$ & Role and responsibility specification with partners & \\
\hline \multirow{4}{*}{$\begin{array}{c}\text { SC } \\
\text { Collaboration }\end{array}$} & $\mathrm{sc} 5$ & Operating agreement with partners & \\
\hline & sc6 & Group decision making with partners & \\
\hline & $\mathrm{sc} 7$ & Group problem solving with partners & \\
\hline & sc8 & Improvement of relationship with partners & \\
\hline \multirow{4}{*}{ SC Integration } & sc9 & Standardization of data with partners & \\
\hline & sc10 & Integration of information system with partners & \\
\hline & sc11 & Repetition removal with partners & \\
\hline & sc12 & Data consistency with partners & \\
\hline \multirow{4}{*}{ SC Agility } & sc13 & Supply chain synchronization & \\
\hline & sc14 & Identification of changes in market environment & \\
\hline & sc15 & Development of new supply chain process & \\
\hline & sc16 & Establishment of contingency plan and crisis management system in the supply chain & \\
\hline \multirow{4}{*}{$\begin{array}{l}\text { Product } \\
\text { Innovation }\end{array}$} & ti1 & New product production & \multirow{8}{*}[44,45]{} \\
\hline & ti2 & New product development speed & \\
\hline & ti3 & New product launch speed & \\
\hline & ti4 & Product mix and product range expansion & \\
\hline \multirow{4}{*}{$\begin{array}{l}\text { Process } \\
\text { Innovation }\end{array}$} & ti5 & Manufacturing technology and process competiveness & \\
\hline & ti6 & Introduction of innovative process and acquisition speed & \\
\hline & ti7 & Introduction speed of high technology and process & \\
\hline & ti8 & Core technology absorption capability & \\
\hline \multirow{5}{*}{$\begin{array}{l}\text { Operational } \\
\text { Performance }\end{array}$} & op1 & Cost structure improvement & \multirow{5}{*}[46,47]{} \\
\hline & op2 & Improvement of quality level & \\
\hline & op3 & Delivery improvement & \\
\hline & op4 & Flexibility improvement & \\
\hline & op5 & Innovation enhancement & \\
\hline
\end{tabular}

\section{Empirical analysis}

\section{Data and descriptive statistics}

Hypotheses are tested on survey data collected from 206 firms that are all small- and mediumsize firms located in Daegu-Gyeongbuk metropolitan area, Korea. The survey was conducted in October 2013. Among the 300 questionnaires, 206 valid research questionnaires were returned. Descriptive statistics of collected data are presented in Table 2 .

\section{Reliability and validation}

A systematic literature review was conducted in order to identify validated items. Measurement instruments used in this study were reviewed by several researchers and some items on the questionnaire were slightly modified. All measures were anchored on a 7-point Likert scale. After the normality test for the data, tests for reliability and validity were conducted using Confirmatory Factor Analysis (CFA). In the evaluation of measurement instruments by CFA, criteria for meeting reliability and validity requirements are where factor loadings are greater than 0.6 with statistical significance, values of composite reliability (CR) are greater than 0.7, and the Average Variance Extracted (AVE) is above 0.5 [48]. Items such as sc1 (demand information sharing), sc12 (data consistency), sc16 (contingency plan and crisis management), and ti1 (new product production) were removed from the analysis because of poor loadings. Results of the reliability and validity of the measurement instruments are shown in Table 3. All the items meet the criteria for reliability and convergent validity and have factor loadings of more than 0.6, CR of more than 0.8, and AVE of more than 0.6. 
Management and Production Engineering Review

Table 2

Descriptive statistics.

\begin{tabular}{|c|c|c|c|}
\hline \multicolumn{2}{|r|}{ Classification } & Frequency $(n=206)$ & Percent [\%] \\
\hline \multirow{9}{*}{$\begin{array}{c}\text { Korean } \\
\text { Standard } \\
\text { Industrial } \\
\text { Classification }\end{array}$} & Food, Textile, Wood & 21 & 10.19 \\
\hline & Petroleum, Chemicals, Printing & 11 & 5.34 \\
\hline & Pharmaceuticals, Medical appliance, Optics & 13 & 6.31 \\
\hline & Rubber, Non-metal & 22 & 10.68 \\
\hline & Metals, Processing of metals & 27 & 13.11 \\
\hline & Electronics, Electricity & 19 & 9.22 \\
\hline & Motor vehicles, Parts for motor vehicles & 48 & 23.30 \\
\hline & Machinery, Transport equipment & 25 & 12.14 \\
\hline & Others & 20 & 9.71 \\
\hline \multirow{2}{*}{ Type } & Non-venture firms & 121 & 58.74 \\
\hline & Venture firms & 85 & 41.26 \\
\hline \multirow{5}{*}{ Years of operations } & $<=5$ & 23 & 11.17 \\
\hline & $6 \sim 10$ & 54 & 26.21 \\
\hline & $11 \sim 15$ & 48 & 23.30 \\
\hline & $16 \sim 20$ & 45 & 21.84 \\
\hline & $>20$ & 36 & 17.48 \\
\hline \multirow{5}{*}{ Number of employees } & $<=10$ & 73 & 35.44 \\
\hline & $11 \sim 30$ & 71 & 34.47 \\
\hline & $31 \sim 50$ & 36 & 17.48 \\
\hline & $51 \sim 100$ & 11 & 5.34 \\
\hline & $>100$ & 15 & 7.28 \\
\hline
\end{tabular}

Table 3

Results of reliability and validity of measurement instruments.

\begin{tabular}{|c|c|c|c|c|c|c|}
\hline \multicolumn{3}{|c|}{ Variable } & Estimate & t-value & $\mathrm{CR}$ & AVE \\
\hline \multirow{25}{*}{ First order factors } & \multirow{3}{*}{ Supply chain Information Sharing (A) } & $\mathrm{sc} 2$ & 0.94 & - & \multirow{3}{*}{0.92} & \multirow{3}{*}{0.79} \\
\hline & & sc3 & 0.81 & 16.60 & & \\
\hline & & sc4 & 0.92 & 22.59 & & \\
\hline & \multirow{4}{*}{ Supply chain collaboration (B) } & sc5 & 0.86 & - & \multirow{4}{*}{0.94} & \multirow{4}{*}{0.79} \\
\hline & & sc6 & 0.90 & 17.97 & & \\
\hline & & sc7 & 0.91 & 18.43 & & \\
\hline & & sc8 & 0.88 & 16.93 & & \\
\hline & \multirow{3}{*}{ Supply chain integration $(\mathrm{C})$} & sc9 & 0.76 & - & \multirow{3}{*}{0.87} & \multirow{3}{*}{0.70} \\
\hline & & sc10 & 0.89 & 13.31 & & \\
\hline & & sc11 & 0.85 & 12.61 & & \\
\hline & \multirow{3}{*}{ Supply chain agility (D) } & sc13 & 0.84 & - & \multirow{3}{*}{0.89} & \multirow{3}{*}{0.73} \\
\hline & & sc14 & 0.89 & 15.62 & & \\
\hline & & $\operatorname{sc} 15$ & 0.82 & 14.03 & & \\
\hline & \multirow{3}{*}{ Product innovation (E) } & ti2 & 0.78 & 11.75 & \multirow{3}{*}{0.86} & \multirow{3}{*}{0.68} \\
\hline & & ti3 & 0.78 & - & & \\
\hline & & ti4 & 0.90 & 13.59 & & \\
\hline & \multirow{4}{*}{ Process innovation $(\mathrm{F})$} & ti5 & 0.84 & - & \multirow{4}{*}{0.94} & \multirow{4}{*}{0.79} \\
\hline & & ti6 & 0.90 & 17.31 & & \\
\hline & & ti7 & 0.91 & 17.64 & & \\
\hline & & ti8 & 0.90 & 17.14 & & \\
\hline & \multirow{5}{*}{ Operational performance } & op1 & 0.79 & 11.10 & \multirow{5}{*}{0.88} & \multirow{5}{*}{0.61} \\
\hline & & op2 & 0.87 & 12.32 & & \\
\hline & & op3 & 0.78 & 10.94 & & \\
\hline & & op4 & 0.73 & - & & \\
\hline & & op5 & 0.72 & 10.03 & & \\
\hline \multirow{6}{*}{ Second order factors } & \multirow{4}{*}{ Supply chain dynamic capabilities } & (A) & 0.87 & - & \multirow{4}{*}{0.93} & \multirow{4}{*}{0.77} \\
\hline & & (B) & 0.90 & 12.87 & & \\
\hline & & $(\mathrm{C})$ & 0.89 & 10.94 & & \\
\hline & & (D) & 0.85 & 11.57 & & \\
\hline & \multirow{2}{*}{ Technological innovation } & $(\mathrm{E})$ & 0.85 & - & \multirow{2}{*}{0.90} & \multirow{2}{*}{0.82} \\
\hline & & $(\mathrm{F})$ & 0.96 & 10.15 & & \\
\hline
\end{tabular}


As shown in Tables 4 and 5 , the square root of the AVE is greater than the correlations between the constructs and all other constructs, thus the discriminant validity of the measures was attained.

Table 4

Correlation matrix of the first-order constructs (Note: Diagonal elements in bold are the square root of the average variance extracted (AVE).

\begin{tabular}{|c|c|c|c|c|c|c|c|}
\hline & (1) & (2) & (3) & (4) & (5) & (6) & (7) \\
\hline $\begin{array}{l}\text { 1. Supply chain } \\
\text { information } \\
\text { sharing }\end{array}$ & 0.89 & & & & & & \\
\hline 2. $\begin{array}{l}\text { Supply chain } \\
\text { collaboration }\end{array}$ & 0.83 & 0.89 & & & & & \\
\hline $\begin{array}{l}\text { 3. Supply chain } \\
\text { integration }\end{array}$ & 0.75 & 0.79 & 0.83 & & & & \\
\hline $\begin{array}{l}\text { 4. Supply chain } \\
\text { agility }\end{array}$ & 0.69 & 0.76 & 0.77 & 0.85 & & & \\
\hline $\begin{array}{ll}\text { 5. Product } \\
\text { innovation }\end{array}$ & 0.69 & 0.64 & 0.68 & 0.68 & 0.82 & & \\
\hline $\begin{array}{l}\text { 6. Process } \\
\text { innovation }\end{array}$ & 0.71 & 0.71 & 0.73 & 0.74 & 0.81 & 0.89 & \\
\hline $\begin{array}{ll}\text { 7. } & \text { Operational } \\
\text { performance }\end{array}$ & 0.72 & 0.75 & 0.81 & 0.75 & 0.69 & 0.83 & 0.78 \\
\hline
\end{tabular}

Table 5

Correlation matrix of the second-order constructs (Note: Diagonal elements in bold are the square root of the average variance extracted (AVE).

\begin{tabular}{l|c|c}
\hline & $(1)$ & $(2)$ \\
\hline 1. Supply chain dynamic capabilities & 0.88 & \\
\hline 2. Technical innovation & 0.87 & 0.90 \\
\hline
\end{tabular}

\section{Hypothesis testing}

This study used structural equation modeling (SEM) for hypotheses testing; AMOS was selected as the SEM approach to estimate the research model. Model goodness-of-fit was identified before examining the hypotheses. Common criteria for model goodness-of-fit in SEM were previously suggested $[48,49]$ and the values of fit indices for the research model can be compared with the suggested cutoffs in Table 6. Most of the fit indices satisfy the cutoff values except the NFL and RFL indices. However, these two indices are close to the suggested cutoff values. The authors thus conclude that the research model indicates adequate fit with the observed data so that the hypotheses can be tested using SEM.

Table 6

The model goodness-of-fit of the research model.

\begin{tabular}{c|c|c}
\hline Fit index & Results & Suggested cutoffs \\
\hline$\chi^{2} /$ d.f. & 2.04 & $<3$ \\
\hline RMR & 0.08 & $<0.1$ \\
\hline GFI & 0.83 & $>0.8$ \\
\hline AGFI & 0.80 & $>0.8$ \\
\hline NFI & 0.89 & $>0.9$ \\
\hline RFI & 0.88 & $>0.9$ \\
\hline IFI & 0.94 & $>0.9$ \\
\hline TLI & 0.93 & $>0.9$ \\
\hline CFI & 0.94 & $>0.9$ \\
\hline RMSEA & 0.07 & $<0.1$ \\
\hline
\end{tabular}

The results of the hypotheses testing are illustrated in Fig. 2. The results show that supply chain dynamic capabilities have a positive impact on technological innovation $(\beta=0.86, p<0.01)$ and on operational performance $(\beta=0.48, p<0.01)$ in Hypothesis 1 and Hypothesis 2, respectively. The authors also find that technological innovation has a positive

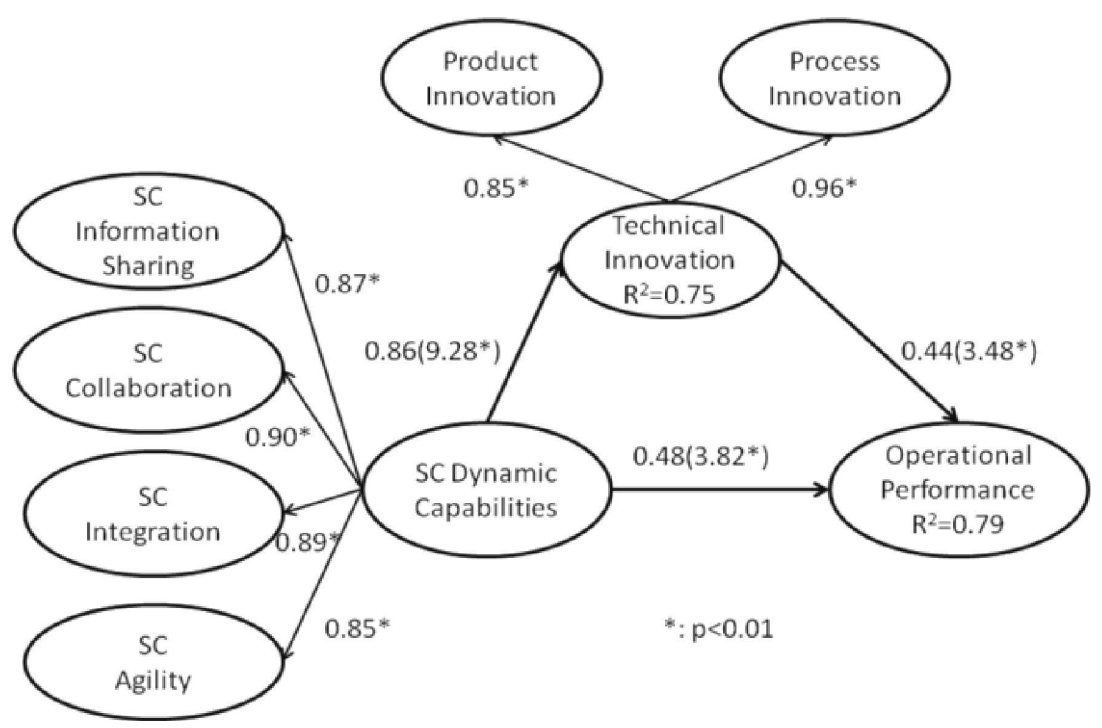

Fig. 2. The model estimation results. 
impact on operational performance $(\beta=0.44, p<$ 0.01), supporting Hypothesis 3. In addition, a Sobel test was conducted to assess whether the indirect effect (mediated effect) was statistically significant [50]. The Sobel test showed a statistically significant mediated effect of technological innovation on the relationship between supply chain dynamic capabilities and operational performance (z-value of $3.19, p<0.01)$.

Also statistically significant was a direct effect between supply chain dynamic capabilities and operational performance. The total effect was 0.86 (not shown in Fig. 2), and the mediated effect 0.38 was smaller. Since an effect is partially mediated when the mediated effect is smaller and of the same sign as the total effect [51], this supports the premise that technological innovation partially mediates the relation between supply chain dynamic capabilities and operational performance as proposed in Hypothesis 4 . Finally, supply chain dynamic capabilities explain $75 \%$ of the variance in technological innovation while $79 \%$ of the variance in operational performance is explained by supply chain dynamic capabilities and technical innovation.

\section{Conclusions}

Supply chain management is the most important factor in today's dynamic and ever-changing global supply chain environment. A supply chain must be flexible in responding to the dynamic changes in a given environment. Based on the dynamic capabilities theory, this study conceptualizes supply chain dynamic capabilities that are quick to adapt to a dynamic environment and proposes a structural relationship of supply chain dynamic capabilities, technological innovation, and operational performance. In addition, the mediation effect of technological innovation was examined. The results of this study are summarized as follows: First, it was confirmed that the development of information sharing, collaboration, integration, and agility of organizations in supply chains are all critical factors to forming supply chain dynamic capabilities. Additionally, supply chain dynamic capabilities in this study are a multidimensional construct with four underlying factors and those factors are strongly related to each other. It is necessary for the organizations in the supply chain to share demand and cost information, maintain collaboration for problem solving and decision making, integrate management, and develop agile supply chains. Second, supply chain dynamic capabilities positively influence technological innovation and operational performance. Information sharing, collaboration, integration, and agility with partners in a supply chain positively affect product and process innovations and improvement of cost, quality, delivery, and flexibility. In particular, the impact on technological innovation by supply chain dynamic capabilities is greater than that on operational performance. Thus, supply chain dynamic capabilities are keys to improving both product and process. Third, technological innovation has a positive impact on operational performance and mediates the relationship between supply chain dynamic capabilities and operational performance. Even though supply chain dynamic capabilities directly influence operational performance, technological innovation as a mediator suggests that improvement in operational performance via technological innovation is desirable.

Even though research on dynamic capabilities has been conducted for a long time in the field of strategic management, little research has been done on dynamic capabilities applied to supply chain management or operations management. Therefore, future studies need to develop additional variables for the dynamic capabilities required by supply chain management and operations management. In addition, further tests should be carried out to identify appropriate supply chain dynamic capabilities based on the type of industry, characteristics of the organization, and the location of the organization along the supply chain.

\section{References}

[1] Ambrosini V., Bowman C., What are dynamic capabilities and are they a useful construct in strategic management?, International Journal of Management Reviews, 11, 1, 29-49, 2009.

[2] Eisenhardt K.M., Martin J.A., Dynamic capabilities: What are they, Strategic Management Journal, 21, 10-11, 1106-1121, 2000.

[3] Teece D.J., Pisano G., Shuen A., Dynamic capabilities and strategic management, Strategic Management Journal, 18, 7, 509-533, 1997.

[4] Teece D.J., Explicating dynamic capabilities: The nature and micro-foundations of (sustainable) enterprise performance, Strategic Management Journal, 28, 8, 1319-1350, 2007.

[5] Barney J.B., Strategic factor markets: Expectations, luck, and business strategy, Management Science, 32, 10, 1231-1241, 1986.

[6] Barney J., Firm resources and sustained competitive advantage, Journal of Management, 17, 1, 99-120, 1991. 
[7] Coyne K.P., Hall S.J.D., Clifford P.G., Is your core competence a mirage?, The Mckinsey Quarterly, 2, 40-54, 1997.

[8] Prahalad C.K., Hamel G., The core competence of the organization, Harvard Business Review, MayJune, 79-93, 1990.

[9] Mentzer J.T., DeWitt W., Keebler J.S., Min S., Nix N.W., Smith C.D., Zacharia Z.G., Defining supply chain management, Journal of Business Logistics, $22,2,1-25,2001$

[10] Kaynak H., Hartley J.L., A replication and extension of quality management into the supply chain, Journal of Operations Management, 26, 4, 468-489, 2008.

[11] Kristal M.M., Huang X., Roth A.V., The effect of an ambidextrous supply chain strategy on combinative competitive capabilities and business performance, Journal of Operations Management, 28, 5, 145-429, 2010.

[12] Wang E.T.C., Tai J.C.F., Wei H., A virtual integration theory of improved supply-chain performance, Journal of Management Information Systems, 23, 2, 41-64, 2006.

[13] Narasimhan R., Talluri S., Das A., Exploring flexibility and execution competencies of manufacturing firms, Journal of Operations Management, 22, 1, 91-106, 2004

[14] Stevenson M., Spring M., Flexibility from a supply chain perspective: definition and review, International Journal of Operations \& Production Management, 27, 7, 685-713, 2007.

[15] Liao S., Wu C., Hu D., Tsui K., Relationships between knowledge acquisition, absorptive capacity and innovation capability: An empirical study on Taiwan's financial and manufacturing industries, Journal of Information Science, 36, 1, 19-35, 2010.

[16] Siqueira A., Cosh A., Effects of production innovation and organizational capabilities on competitive advantage: Evidence from UK small and medium manufacturing enterprises, International Journal of Innovation Management, 12, 2, 113-137, 2008.

[17] Timilsina B., Forsen N., Takala J., Malek N.A.A., Which one to choose multi focus or tradeoff among competitive priorities? Evidence from Finnish SMEs, Management and Production Engineering Review, 7, 1, 77-88, 2016.

[18] Hubbard R., Vetter D.E., Little E.D., Replication in strategic management: scientific testing for validity, generalizability, and usefulness, Strategic Management Journal, 19, 3, 243-254, 1998.

[19] Miguel P.L.S., Ledur Brito L.A.L., Supply chain management and its influence on operational per- formance, Journal of Operations and Supply Chain Management, 4, 2, 56-70, 2011.

[20] Flynn B.B., Flynn E.J., Synergies between supply chain management and quality management: Emerging implications, International Journal of Production Research, 43, 16, 3421-3436, 2005.

[21] Shin H., Collier D.A., Wilson D.D., Supply management orientation and supplier/buyer performance, Journal of Operations Management, 18, 3, 317-333, 2000 .

[22] Wheeler B.C., NEBIC: A dynamic capabilities theory for assessing net-enablement, Information Systems Research, 13, 2, 125-146, 2002.

[23] Devaraj S., Krajewski L., Wei J.C., Impact of ebusiness technologies on operational performance: The role of production information integration in the supply chain, Journal of Operations Management, 25, 6, 1199-1216, 2007.

[24] Flynn B.B., Huo B., Zhao X., The impact of supply chain integration on performance: A contingency and configuration approach, Journal of Operations Management, 28, 1, 58-71, 2010 .

[25] Swink M., Narasimhan R., Wang C., Managing beyond the factory walls: Effects of four types of strategic integration on manufacturing plant performance, Journal of Operations Management, 25, 1, 148-164, 2007

[26] Wong C.Y., Boon-itt S., Wong C.W.Y., The contingency effects of environmental uncertainty on the relationship between supply chain integration and operational performance, Journal of Operations Management, 29, 6, 604-615, 2011.

[27] Lee H., The triple-A supply chain, Harvard Business Review, 102-112, 2004.

[28] Frohlich M.T., E-intergration in the supply chain: barriers and performance, Decision Sciences, 33, 4, 537-556, 2002

[29] Kim D., Lee R.P., Systems collaboration and strategic collaboration: Their impacts on supply chain responsiveness and market performance, Decision Sciences, 41, 4, 955-981, 2010.

[30] Dewar R.D., Dutton J.E., The adoption of radical and incremental innovations: an empirical analysis, Management Science, 32, 11, 1422-1433, 1986.

[31] Ettlie J.E., Bridges W.P., O'Keefe R.D., Organization strategy and structural differences for radical versus incremental innovation, Management Science, 30, 6, 682-695, 1984.

[32] Benner M.J., Tushman M.L., Exploitation, exploration, and process management: The productivi- 
ty dilemma revisited, Academy of Management Review, 28, 2, 238-256, 2003.

[33] Gupta A.K., Smith K.G., Shalley C.E., The interplay between exploration and exploitation, Academy of Management Journal, 49, 4, 693-706, 2006.

[34] Damanpour F., Organizational innovation: a metaanalysis of effects of determinants and moderators, Academy of Management Journal, 34, 3, 555-590, 1991.

[35] Chuang L., An empirical study of the construction of measuring model for organizational innovation in Taiwanese high-tech enterprises, The Journal of American Academy of Business, 9, 2, 299-304, 2005.

[36] Neely A., Filippini R., Forza C., Vinelli A., Hii J., A framework for analysing business performance, firm innovation and related contextual factors: Perceptions of managers and policy makers in two european regions, Integrated Manufacturing Systems, 12, 2, 114-124, 2001.

[37] Melnyk S.A., Stewart D.M., Swink M., Metrics and performance measurement in operations management: Dealing with the metrics maze, Journal of Operations Management, 22, 3, 209-217, 2004.

[38] Rosenzweig E.D., Roth A.V., Towards a theory of competitive progression: evidence from high-tech manufacturing, Production \& Operations Management, 13, 4, 354-368, 2004.

[39] Flynn B.B., Flynn E.J., An exploratory study of the nature of cumulative capabilities, Journal of Operations Management, 22, 5, 439-457, 2004.

[40] Peng D.X., Schroeder R.G., Shah R., Linking routines to operations capabilities: A new perspective, Journal of Operations Management, 26, 6, 730-748, 2008 .

[41] Peng D.X., Schroeder R.G., Shah R., Competitive priorities, plant improvement and innovation capabilities, and operational performance: A test of two forms fit, International Journal of Operations \& Production Management, 31, 5, 484-510, 2011.

[42] Li Y., Xie E., Teo H.H., Peng M.W., Formal control and social control in domestic and international buyer-supplier relationships, Journal of Operations Management, 28, 4, 333-344, 2010.

[43] Wu F., Yeniyurt S., Kim D., Cavugil S.T., The impact of information technology on supply chain capabilities and firm performance: A resource-based view, Industrial Marketing Management, 35, 4, 493$504,2006$.

[44] Camison C., Lopez A.V., An examination of the relationship between manufacturing flexibility and firm performance, International Journal of Operations \& Production Management, 30, 8, 853-878, 2010 .

[45] Prajogo D.I., McDermott C.M., The relationship between multidimensional organizational culture and performance, International Journal of Operations \& Production Management, 31, 7, 712-735, 2011.

[46] Rai A., Patnayakuni R., Seth N., Firm performance impacts of digitally enabled supply chain integration capabilities, MIS Quarterly, 30, 2, 225-246, 2006.

[47] Sanders N.R., IT Alignment in supply chain relationships: A study of supplier benefits, Journal of Supply Chain Management, 41, 2, 4-13, 2005.

[48] Hatcher L., A Step by Step Approach to Using SAS for Factor Analysis and Structural Equation Modeling, NC: SAS Publishing, 2003.

[49] Cheung G.W., Rensvold R.B., Evaluating goodnessof-fit indexes for testing measurement invariance, Structural Equation Modeling, 9, 2, 233-255, 2002.

[50] Sobel M.E., Asymptotic confidence intervals for indirect effects in structural equation models, Sociological Methodology, 13, 290-312, 1982.

[51] Shrout P.E., Bolger N., Mediation in experimental and nonexperimental studies: new procedures and recommendations, Psychological Methods, 7, 4, 422445, 2002. 